\title{
Free and Open Source Software Across the EU
}

\author{
Gijs Hillenius $^{(a)}$ \\ (a) Journalist, contributor to Joinup
}

DOI: $\underline{10.5033 / \text { ifosslr.v5i2.90 }}$

\begin{abstract}
Across the EU, there is a groundswell of public administrations that use open source for their ICT solutions. Evidence of its benefits as well as practical examples are steadily piling up at the European Commission's Open Source Observatory. The areas where this type of solution can be found most include, in random order, content management (CMS), document management (DMS), database applications, all kinds of online e-government services, geo-information systems (GIS) and in most if not all publicly provided applications built to use open data.
\end{abstract}

\section{Keywords}

Public administrations; European Union; Joinup; Free and Open Source Software Policies; implementations.

When it comes to free and open source software (FOSS), many public administrations will have stumbled across it. These days, their IT dealer tells them that their proprietary system for managing citizen records will function just as well with the open source database management system Postgresql, yet the subscription fee is much lower than when combined with the previously required proprietary alternative. ${ }^{1}$

For others, switching to free and open source is increasingly a conscious decision. This is because city administrations such as that of Germany's Munich, the Spanish cities Zaragoza, Bilbao and Badajoz, Portugal's Vieira do Minho, Denmark's second-largest city Århus, the Dutch city of Ede, the towns of Grygov and Jihlava in the Czech Republic, the village of Arles in the south of France, Poland's Poznan and Italy's Bologna are grokking open source. To encourage these clever public administrations, the past few years several EU member states have adopted laws and guidelines giving preferential treatment to this type of software.

A list of country's with the best policies on free and open source must begin with France. It produced a thorough review of the benefits of free software, the so-called "Ayrault Circular" which was adopted by the French government in September 2012. The circular provides a roadmap helping ministries create their free software strategy. The guideline came to existence by virtue of the Adullact network of civil servants involved in free software IT development and its many, many

1 https://joinup.ec.europa.eu/community/osor/news/dutch-town-switches-postgresql-open-source-database 
ministries already doing amazingly much with open source. ${ }^{2}$

It is thanks to a question by a member of France's parliament, Isabelle Attard (Europe Ecology - The Greens), that we are beginning to learn how normal open source has become in France's ministries. ${ }^{3}$ In May, MP Attard asked all ministries about their implementation of the Circulaire Ayrault.

\section{Policy Hitparade}

This summer, the 37 ministries and ministerial departments have slowly begun to respond. Their answers range from enthusiast to subdued and downright aloof.

One of the more electrifying replies is by France's education ministry. It reveals that it has over 23,000 servers based on Ubuntu Linux that since 2001 are used in schools across the country and used for network and system security as file servers, backup servers, for VPN and for serving applications to thin clients. The ministry itself has been using Linux "for over a decade": its service departments host over 4,000 Red Hat Linux servers, and "the OpenOffice and LibreOffice office suites are widely used by teachers as a tool to work and share with students."

Unruffled, the Ministry of Economy and Finance responds to Attard that it has been using open source for over a decade, with Linux now used for most servers and email based entirely on open source. This includes the use of these types of solutions on workstations: "By 2003, all workstations of the General Directorate of Customs and Excise migrated to a free office suite."

The most distant is the Ministry of Defence - criticised earlier this year by parliament over its renewing of a proprietary licence contract, bypassing public procurement ${ }^{4}$. The ministry curtly explains Attard that it does not distinguish proprietary software from free software in its accounting systems. Software purchases are included in contracts that focus on development, integration or maintenance. That makes it hard to exclude the purposes from the cost of the licences. The assessment is complex, the ministry writes, as software is included in so many electronic devices, including phones, radios and even satellites.

\section{Issues with Interoperability}

Contender for first place on the list is Spain. It has appealing region policies, such as that adopted by the Basque region (see side bar 'A EU directive for future benefits'). But, nationally, it is the Royal Decree 4/2010 on the National eGovernment Interoperability Framework that is supporting open document formats and that is emboldening a growing number of administrations. A good illustration is the city of Zaragoza which is using the law to remind others that the government wants them to use open formats. ${ }^{5}$

The capital of the autonomous community of Aragon has been using OpenOffice, a suite of office productivity tools, on all of the city's 3200 PCs since 2007. Recently, Zaragoza started to also use LibreOffice. As Eduardo Romero, the IT specialist leading the desktop migration project for the city administration, points out, since both suites use the Open Document Format, there are no interoperability problems between the two. Such issues do arise when communicating with

2 https://joinup.ec.europa.eu/community/osor/news/ministries-france-detail-use-and-plans-free-software

3 https://joinup.ec.europa.eu/community/osor/news/ministries-france-detail-use-and-plans-free-software

4 https://joinup.ec.europa.eu/news/french-advocacy-group-decries-defences-ignoring-procurement-law

5 https://joinup.ec.europa.eu/community/osor/news/spains-zaragoza-continues-gradual-switch-open-soure 
organisations that do not support open formats, he says. "We have to remind these organisations that there is a very clear law prescribing the use of open formats."

A side effect of this is that Zaragoza is pointing others the way. "When we began using OpenOffice we were one of the few", says Romero. "Now, there are many public administrations and companies that switched and we have helped quite a few to take their first steps."

\section{An EU Directive for Future Benefits}

The European Union should start working on a directive on openness and reuse of software applications, says Serafín Olcoz Yanguas, a former chief information officer of Basque Country. Governments that switch to free and open source software contribute to the economy and improve productivity, he argues. "It is a more efficient business model than that of the proprietary software industry." ${ }^{6}$

Governments using open source create future benefits (CAPital EXpenditures), as part of their OPerational EXpenditure, argues Olcoz. "It creates a virtuous loop between the public and private sector, with a recurring public contribution."

Olcoz launched his proposal during the Libre Software World Conference, which took place in Santiago de Compostela on 18 and 19 October 2012. He would prefer the EU directive to be based on the decree proposed by the Basque government in July and approved as a policy in September that year. That law says that all software developed for the government publicly must be made available as open source.

Third comes Italy, which made open source the preferred choice in its Digital Administration Code in 2012. How to compare incomparable open and closed source IT solutions; that has been parked in a committee that will, duly, take its time. In May, lawyer Ernesto Belisario, professor at University of Basilicata in the city of Potenza, reported that the discussion in the working group is stalling. "Some of the members think the law stipulates a technical and economical assessment, instead of reading it as a statement supporting open source." ${ }^{7}$

So, maybe this third place should actually be for Sweden. Here a dexterous public procurement plan, written by the Kammarkollegiet, organises support for public administrations procuring open source. ${ }^{8}$ It is growing faster in amounts of turnover than any other procurement framework contract has ever done before. Although, to be honest, all the Swedes seem to do is buy support for Drupal, Alfresco and Red Hat. ${ }^{9}$

\section{Upstream Developments}

This example deserves a second look as the procurement framework includes terms and requirements never seen before. If an open source solution is customised by a public administration, or a subcontractor adds some lines of code, the lead software firm is made responsible for delivering this code to the upstream project.

6 https://joinup.ec.europa.eu/news/basque-country-wants-european-directive-reuse-software

7 https://joinup.ec.europa.eu/community/osor/news/governmental-working-group-stalling-italys-switch-open-source

8 https://joinup.ec.europa.eu/elibrary/case/public-open-source-software-procurement-models-next-generation

9 https://joinup.ec.europa.eu/news/se-framework-agreement-increases-use-open-source 
The framework also takes away the perceived risks for public administrations by making the software company responsible for distribution. They have to make sure they have the rights to do that and to deal with potential royalties, if any.

The framework contracted five suppliers that potentially provide software and services to the central government, the public educational sector, and all twenty county councils. Of all 290 Swedish municipalities, 225 are participating in this framework. These five firms, in turn, are allowed to subcontract for a total of 75 companies to provide required competences and services. The Swedish framework is therefore a tree, branching to include many open source specialists. These are not the typical companies fulfilling government contracts. It includes two one-man shops and a firm with about 180 employees, so both Sweden's smallest and biggest open source companies.

This procurement approach is now available in German. ${ }^{10}$ They were translated on the request of the Swiss government's Federal IT Steering Unit FITSU. The Swiss public administrations are considering a similar approach. Maybe this is a good idea for Germany to mimic.

\section{Slow Execution}

For completeness sake, one has to mention the Netherlands. Here a slew of government organisations are continuing to push the same open standards and open source plans that were advocated by the now-defunct NOiV government programme. Advocates include the 'Standardisation Board and Forum', which "supports the Dutch government in the use, development and establishment of open standards for electronic exchange", and KING, an umbrella organisation to assist the country's municipalities with their e-government services.

\section{Taxing Citizens}

It is the taxes, stupid. It is not surprising that Germany comes tenth and the Netherlands is first on the United Nation's e-government ranking for Europe (2012). ${ }^{11}$ The Dutch government simply cuddles their taxpayers: to pacify even the most rebellious, the Tax Authorities are since 2006 making available a Linux-client to allow these to file their annual income tax. In Germany, in 2013 Elster continues to ignore the vocal Linuxcitizens.

Jokes about the open source tax solutions aside (see side bar 'Taxing citizens'), when surveying the EU member states on free software policies, it seems that the public administrations in Germany and in the United Kingdom are still frightened by open source. Why? At least in Germany they can turn to well-organised commercial support. There is, for example, the OSB Alliance, offering a stack of open source solutions that they assure can be combined seamlessly. This business network contains plenty of German and German-speaking ICT service providers, offering their assistance for groupware, customer relationship management, enterprise resource planning, document management, business intelligence and access management. The stack includes middleware, operating system, backup and archive solutions.

One big difference between Germany and the United Kingdom is that Germany lacks national political support for open source. The country does have an Open Source Kompetenzcentrum, but it

10 https://joinup.ec.europa.eu/community/osor/news/swiss-government-consider-re-use-swedish-open-source-procurementprogram

11 htp://www.un.org/en/development/desa/publications/connecting-governments-to-citizens.html, page 45 
is in a zombie state. Over the past two, three years it has never answered any of the questions fired at them in spite of some talk of it being revamped. Likewise, the Ministry of the Interior must be under a gag order since its civil servants over the same period have never ever responded to any query concerning open source. Here, as well as in most other EU member states, the only politicians that drum up the courage to speak out are on the left side of the political spectrum. To quote Dutch politician Femke Halsema: "Odd that parties on the left have to explain the liberals about competition." 12

On the other hand, the United Kingdom has dressed up an impressive ICT policy, complete with an "Open Source Procurement Toolkit". ${ }^{13}$ The UK's current coalition government decided in 2011 that "where appropriate, government will procure open source solutions." 14

However, whether or not to include the United Kingdom in the list of countries with policies favouring free and open source, that is the question. The islanders seem very hesitant in the execution of this policy. The well-known example of Bristol aside,,$^{15}$ the only two recent examples are Leeds Teaching Hospitals, ${ }^{16}$ implementing an open source hospital information system, and the country's central site for government services and information, Gov.uk, built on Drupal. ${ }^{17}$ It is also impossible to get the spokespersons of the Department for Work and Pensions to say anything on their open source pilot even though it was announced way back in December 2011. In the UK, as in all other EU member states, the ICT sector public administrations find it particularly difficult to make unencumbered technological choices.

\section{Comparing Made Compulsory}

There are three more countries that have plans involving open source worth mentioning. First, the government of Portugal in September 2013 announced that it wants to increase its use of open source ICT solutions and open ICT standards aiming to rationalise its IT and reduce costs. The new IT direction was unveiled by André Vasconcelos from the Agency for Administrative Modernisation (AMA) speaking at the Evento Linux Conference in Lisbon on 26 September. "To allow comparing open source and proprietary solutions, we'll make it compulsory to calculate the Total Cost of Ownership over 4 years, including for maintenance, licences, migration and productivity." 18

Second, in 2012, the government of Iceland famously announced it would start switching to open source. "The goal of the project is not to migrate public institutions to free and open source software in one single year, but to lay a solid foundation for such a migration which institutions can base their migration plans on”, Tryggvi Björgvinsson, the project leader, told Joinup. ${ }^{19}$

And third, Estonia is creating modern e-government services mainly by using free and open source software. "All our key projects become open source, including the systems for health care, police, business portals, document exchange, the software for e-Justice, a citizen portal and software for eProcurement and e-Invoicing", Siim Sikkut, ICT Policy Adviser for the government, said at an e-

12 Quoted in an article by the author, in the Dutch Linux Magazine \#1, 2008

13 https://www.gov.uk/government/publications/open-source-procurement-toolkit

14 https://www.gov.uk/government/publications/open-source-procurement-toolkit

15 http://www.slideshare.net/zaiziltd/changing-bristol-underpinning-the-creation-of-a-future-council-with-open-source-andopen-standards

16 http://www.ehealthopensource.com/case-studies/leeds-teaching-hospitals-nhs-trust/

17 https://www.gov.uk/

18 https://joinup.ec.europa.eu/community/osor/news/portuguese-government-set-increasing-use-open-source

19 https://joinup.ec.europa.eu/news/all-icelands-public-administrations-moving-towards-open-source 
government conference taking place in Singapore on 22 May 2013. ${ }^{20}$ The country also by default makes all of its software solutions available using the European Public Licence, EUPL.

\section{Guidance on Standards-Based ICT}

And the European Commission? The EC says that is has set out to tackle the problem of IT vendor lock-in at its root. ${ }^{21}$

To help public administrations to get their ICT procurement right, the Commission in 2011 started a project as a part of Action 23 of the Digital Agenda for Europe. This action is "committed to providing guidance on the link between ICT standardisation and public procurement, to help public authorities to use standards to promote efficiency and reduce lock-in."

The European Commission finally published its 'Guide for the procurement of standards-based ICT' in June $2013 .{ }^{22}$ The guide is meant to be a practical tool to help procurers, IT managers, strategists and architects decide which standards are relevant and useful.

ICT systems based on standards boost interoperability, innovation and competition while lowering costs, EC wrote in its announcement of the guide. Such ICT solutions will also improve interaction with citizens. "Making better use of standards allowing competitors to provide alternative solutions will diminish lock-in and increase competition."

The guide warns public administrations to ensure that the standards they select do not contain barriers to implementation by all interested parties. The examples mentioned in the guide are interesting. It starts, for example, with SQL (Structured Query Language); this is a database querying language created in the seventies, and standardised by ISO in 1987 (ISO 9075). "However, interoperability problems between major products still exist due to different interpretations of the standard, due to room for interpretation and the complexity of the standard. There remains the possibility of lock-in for suppliers using this standard."

\section{Unexpected Warning}

A fascinating exercise is comparing the draft guide (available already in late 2012) with the version published in June. Contrasting the earlier version, the latter now also warns public administrations to be careful with ISO/IEC 26300 (Open Document Format) next to the two already signalled in the draft texts ISO/IEC 29500 (Microsoft's OOXML) and ISO 32000 (PDF). All three standards for document formats "reference information that is not accessible by all parties."

Startled, the Open Document Foundation in August asked the EC why it had in the last minute included ODF. The EC replied that it had discovered a dead link in the specification at the section $17.7 .3^{23}$ of the ISO standard. Interestingly, ODF's standard setting organisation OASIS had already fixed these links three years ago. ${ }^{24}$

Whether or not an update will reflect this, the guide alone will probably not be enough for public administrations to get rid of IT vendor lock-in, says Jutta Kreyss, introduced as Munich's IT architect

20 https://joinup.ec.europa.eu/community/osor/news/estonias-government-relies-strongly-open-source

21 https://joinup.ec.europa.eu/news/kroes-replies-munich-standards-it-procurement-will-tackle-problem

22 https://joinup.ec.europa.eu/community/osor/news/ec-calls-use-ict-standards-battle-it-vendor-lock

23 http://www.isi.edu/in-notes/iana/assignments/media-types/media-types

24 https://www.oasis-open.org/apps/org/workgroup/office/download.php/49989/OpenDocument-v1.1-errata01-wd09.zip 
speaking to the European Parliament's Committee on Legal Affairs: "Standards alone are insufficient for any non-simple IT project. To get out of the vendor-lock in, one has to use standards and open source."

The IT architect told the parliamentarians that even if the same SQL standard was used in database systems, that does not make it possible to switch easily from one proprietary database management system to another. "The EC thinks demanding the use of IT standards will fix this? It is not true."

Kreyss told the Committee members that the EC is one of the big inhibitors to public administrations like Munich. "We often have to deal with requests from the EC that force us to use a proprietary operating system and office suite. And that is not just expensive. The European Commission should accept and work with the open document format ODF."

\section{Dark Clouds}

Across the EU, public administrations are using open source solutions in their IT. They do not talk about it much, but call them and they will point out a tool or two that they use daily that is open source, or based on open source.

Examples are steadily aggregated by the Open Source Observatory, a project by the European Commission. Here, in the International Free and Open Source Software Law Review space restrictions prevent to describe them all in detail, but for those that want examples on how to organise this, read up on Sweden's Kivos, Norway's Frikomport and Belgium's Mimio. Also worth a good look are the many projects in France developed by OpenMarie, or by the Danish municipalities working together on Drupal (OS2Web) and Library solutions (T!ng). There are many encouraging examples in every country, including Italy, Greece, Cyprus, Portugal and Ireland.

However, there are three problems. First: as readers will know, there is one particular area where this type of software lacks visibility and that is the desktop. This is the part of the government software market that suffers much from vendor lock-in and this is where user habits make it difficult to change. See, for example, Freiburg, or Amsterdam, or Helsinki, or the German ministry of Foreign Affairs.

Second, public administrations are moving their ICT to the cloud. And the way they are doing that will not at all solve the conundrum of IT vendor lock-in. It is a good thing that the next European OpenSource \& Free Software Law Event, this December, will be considering "Open Source in Cloud Strategies". Recent examples featured on Joinup show that public administrations are moving to using cloud-based open source solutions.

\section{Reporting Problems}

The Norwegian free software association for municipalities, Friprogforeningen, in January 2013 started offering cloud-based open source applications. This means municipalities can use open source tools such as the Redmine project management and bug-tracking tool and the OTRS service management and helpdesk software without having to install and maintain the applications ${ }^{25}$.

Other examples of this would include Kivos, with the national roll-out this summer of Fixa min

25 https://joinup.ec.europa.eu/news/norways-municipalities-run-open-source-apps-open-source-cloud 
Gata. ${ }^{26}$ This is Sweden's version of the UK's Fix My Street, a web and smart-phone solution to allow citizens to easily report problems with streets and roads, including potholes, broken side-walks, graffiti and non-functioning lampposts. It is now also employed in the Brussels Region in Belgium ${ }^{27}$, and in Ireland where Local Government Management Agency is using it to lure municipal administrations to trying out open source. ${ }^{28}$ The question is, do all these public administrations realise they are using an open source solution, or will it to them be just like any other web-service? If the latter, will they lose the incentive to contribute to future versions of the code?

And third, sticking to the IT procurement continues to be problematic. Almost one in every five procurement requests makes illegal references to specific brands or products. According to OpenForum Europe, ${ }^{29}$ a UK-based advocacy group lobbying the UK and EU governments: "Almost one in five, 19 per cent, includes technical specifications with explicit references to trademarks. That is the highest in the last three years."

Even the European Commission makes such errors. ${ }^{30}$ Possibly even worse, the EC could be showing public administrations the way. In a speech in October 2012 at the European OpenSource \& Free Software Law Event, in Paris, Mathieu Paapst, a legal researcher at the University of Groningen in the Netherlands, lambasted the EC for breaking its own rules. ${ }^{31}$

According to Paapst, in 2011 the EC tricked the rules when it purchased proprietary Windows licenses for the workstations used at the Commission and 41 other European agencies. He argues that the EC evaded proper procurement by, first, claiming exceptionally that it had no alternative but to specify the proprietary Windows brand name to describe what it wanted, and then, second, organising a negotiated procurement procedure with the one and only Windows vendor. "When there is an alternative, the second, the negotiated procedure does not allow the use of the first, the exception to specifying brand names."

So far, Paapst says, he has approached his EC contacts in vain with his message. "We know that there are alternatives, such as Linux or Apple's Mac OS X. Even the European Court knows there are alternatives."

\section{Tip of the Iceberg}

The desktop may be the most problematic to change, but there are fearless public administrations. The top three of public administrations that use open source, not just for websites and servers but also across the majority of their desktop PCs, are the French Gendarmerie, the government of Spain's Extremadura region and the city of Munich.

The French Gendarmerie are migrating 85,000 PCs in 45,000 police stations. They are converting 10,000 PCs per year. The project is foreseen to be completed in 2015, with $90 \%$ of the PCs switched to free and open source. That is a similar percentage as in Munich, coincidentally.

Why did the Gendarmerie switch? Well, in the end it happened because of protests from a proprietary vendor to one of the Generals about an IT staffer that was experimenting with an open

\footnotetext{
26 https://joinup.ec.europa.eu/community/osor/news/fix-my-street-proves-benefit-open-source-swedish-towns

27 https://joinup.ec.europa.eu/news/swedish-municipalities-re-use-uks-fix-my-street-web-application

28 https://joinup.ec.europa.eu/community/osor/news/ireland-agency-helps-local-governments-beat-open-source-fear

29 https://joinup.ec.europa.eu/news/openforum-europe-procurement-law-fails-address-discriminatory-practices

30 http://www.computerweekly.com/blogs/public-sector/2012/07/-the-european-commission-has.html

31 http://eolevent.eu/ca/node/429
} 
source $^{32}$ spreadsheet. At least, that is what Lieutenant-Colonel Xavier Guimard told the attendees of a Dutch open source conference in 2006.

He also said that move to open source has helped to reduce maintenance costs. Keeping GNU/Linux desktops up to date is much easier, he says. "Previously, one of us would be travelling all year just to install a new version of some anti virus application on the desktops in the Gendarmerie's outposts on the islands in French Polynesia. A similar operation now is finished within two weeks and does not require travelling."

In October 2013, the Gendarmerie again made headlines in IT trade publications around the world, following Joinup's report on a presentation by Major Stéphane Dumond, at the Evento Linux conference in Lisbon. The Major reported that using an open source desktop lowers the total cost of ownership by $40 \%$, in savings on proprietary software licences and by reducing costs on IT management. ${ }^{33}$ "Using Ubuntu Linux massively reduces the number of local technical interventions."

For the French police force, the industrialised open source desktop is a powerful lever for IT governance, Major Dumond says. "The direct benefits of saving on licences are the tip of the iceberg."

\section{Low Budget}

The government of Spain's Extremadura autonomous region has 70,000 PCs running Linux (based on Debian, translated into Spanish and with some local tweaks and applications included) in schools (mostly dual-boot). The same distribution runs on 15,000 PCs in local hospitals. And, if all is well, there is a switch under way to Ubuntu Linux or something similar for 40,000 PCs in all the offices of the regional administration. ${ }^{34}$

This desktop migration project is titled 'Challenge'. Extremadura's CIO Theodomir Cayetano explained that moving to open source will allow the administration to unify all the desktops, make the desktops easier to manage, make the desktops more secure and less prone to viruses and to make it easier to manage the desktops (centrally). ${ }^{35}$

There could be trouble, says Cayetano, as the administration does not have a lot of budget to spare for the migration.

\section{Political Support}

The achievements of the city of Munich are well known. The city has migrated close to 14,000 desktops and along the way created several interesting open source solutions, including the template management tool Wollmux, ${ }^{36}$ one of the most popular projects on Joinup. It helps manage forms and templates and, for example, makes creating procurement requests much easier. It runs only on LibreOffice and OpenOffice and, according to one of the Munich developers, some of the civil servants in Freiburg love it so much that they are regretting having to switch back to the tired proprietary office suite.

32 http://joinup.ec.europa.eu/news/fr-gendarmerie-saves-millions-open-desktop-and-web-applications

33 https://joinup.ec.europa.eu/community/osor/news/french-gendarmerie-open-source-desktop-lowers-tco-40

34 http://joinup.ec.europa.eu/community/osor/news/spains-extremadura-starts-switch-40000-government-pcs-open-source

35 http://joinup.ec.europa.eu/news/extremadura-move-all-its-40000-desktops-open-source

36 https://joinup.ec.europa.eu/software/wollmux/description 
The Limux project is probably the world's most well-known example of a public administration moving to open source. That is in a major part thanks to Munich's mayor, Christian Ude. "The main reason for such a project to fail is the lack of political support", Jutta Kreyss, IT-architect for the German city of Munich, told the European Parliament Committee on Legal Affairs, in Brussels in July 2013.

Munich's switch took a decade, involved a centralisation of 22 IT departments and the standardisation of applications and IT management which affected all 33,000 employees in the 51 locations across the city. Of course there were conflicts. Yet, Kreyss told the EP, these meetings where convened in the office of the mayor. "You can imagine how helpful that is, in getting it done."

\section{"Freedom from What?"}

Europe has few politicians like Ude that can take credit for making a stand on using free and open source. In June, when the city hosted a two-day conference to celebrate the completion of the project, the mayor recounted his main motivation to push for free and open source. The ubiquitous proprietary desktop vendor had rudely demanded the city updates its operating system, he said, as the then-used version was no longer being supported. "No other sector suffers from this kind of vendor lock-in", Ude said. "Not even an industry specialised in the construction of tunnels."

The confrontation clearly hardened his resolve. He even discussed the switch with Bill Gates, at a time when he was still the chairman of Microsoft.

Ude, who was on his way back from a speech at an IT conference in California, was offered a ride to the airport by Gates. The chairman showed up with a big van with tinted windows and had hoped to have a long talk about this Linux project, Ude said.

Gates: "Why are you doing this?" Ude, remarking aside that he has trouble speaking in English, punctuated: "To gain freedom!" Gates had to think about this for a bit, Ude said, but then asked: "Freedom? From what?" Ude: "From you!"

The rest of the trip to the airport passed in silence.

\section{European Initiatives}

There are plenty of examples of open source to be found in the European institutions. One interesting example would be the European Citizen's Initiative. The project is proving quite a challenge, involving the Commission, the European Parliament and many influential NGOs from across the EU, including from Berlin. The project could be suffering from feature creep, ${ }^{37}$ but should slowly become one of the first examples of how a large-scale public administration successfully interacts with the open source community.

A second example is Open e-Prior, ${ }^{38}$ an open source solution to manage e-(electronic) invoicing. The application is used by the European Commission, and recently the Belgian federal IT services decided they too will now begin to use it. ${ }^{39}$

37 https://en.wikipedia.org/wiki/Feature creep

38 http://ec.europa.eu/isa/actions/01-trusted-information-exchange/1-7action_en.htm

39 https://joinup.ec.europa.eu/software/epriortools/news/belgium-adopts-european-commission-system-e-invoicing 
But so far the nicest example of an open source software solution developed by a European institution is AT4AM. This is software for authoring and management of amendments on parliamentary texts used by the European Parliament. AT4AM makes its texts instantly available in 23 languages. This means that users can submit amendments in their own language, but it also helps translators to quickly find the relevant parts of the documents. It uses an OASIS open standard, LegalDocML (previously known as Akoma Ntoso), ${ }^{40}$ which started the development, by the United Nations, for use in the IT systems in several of the parliaments in Africa. It defines "a machine readable set of simple technology-neutral electronic representations (in XML format) of parliamentary, legislative and judiciary documents". AT4AM is available as free and open source software since March this year, published under the European Union's public licence, the EUPL. ${ }^{41}$

\section{About the author}

Gijs Hillenius is an independent Dutch journalist. Since 2007, he has written over 1500 news items on public administrations and open source for the Open Source Observatory, a community on the European Commission's Joinup platform for sharing and re-use of ICT solutions.

The platform also hosts several tens of case studies (adding one per month) and now counts 4,400 software projects tailored to public administration and attracts some 80,000 visitors per month.

Joinup is also where you can find the EUPL. That is the licence used primarily by the European Commission. You could call it a fork of the GPL, to better fit the copyright laws in all the EU member states. The one really nice thing about the EUPL is that it is legally identical in all the 22 languages in which it is available.

40 http://www.akomantoso.org/

41 https://joinup.ec.europa.eu/news/european-parliament-releases-its-amendment-software-open-source 


\section{Licence and Attribution}

This paper was published in the International Free and Open Source Software Law Review, Volume 5, Issue 2 (December 2013). It originally appeared online at http://www.ifosslr.org.

This article should be cited as follows:

Hillenius, Gijs (2013) 'Free and open source software across the EU', International Free and Open Source Software Law Review, 5(2), pp 153 - 164 DOI: 10.5033 ifosslr.v5i2.90

Copyright @ 2013 Gijs Hillenius.

This article is licensed under a Creative Commons UK (England and Wales) 2.0 licence, no derivative works, attribution, CC-BY-ND available at http://creativecommons.org/licenses/by-nd/2.0/uk/

As a special exception, the author expressly permits faithful translations of the entire document into any language, provided that the resulting translation (which may include an attribution to the translator) is shared alike. This paragraph is part of the paper, and must be included when copying or translating the paper.

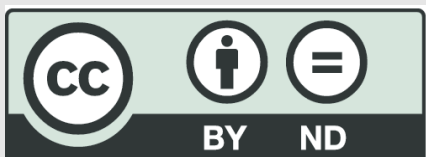

